\title{
Openspace Transformation in Conservation Area
}

\author{
Bangun IR Harsritanto ${ }^{1 *}$, Kezia ES Dewi ${ }^{2}$, Tia Hetwisari ${ }^{3}$ \\ 1 Architecture Department of Engineering Faculty, Universitas Diponegoro, Semarang - Indonesia \\ ${ }^{2}$ Architecture Department of Engineering Faculty, Universitas Riau Kepulauan, Batam - Indonesia \\ ${ }^{3}$ Ministry of Public Works and Housing, Indonesia
}

\begin{abstract}
People demands on open public spaces were never declined. Nowadays urban parks take great role again as green area of the city and place of people interactions. In other hand, conservation shall be protected as part of historical site. Both area have requirements to be followed. The intersection between open space transformation and protected conservation area become this study object. The purpose of this study is to investigate and analyze the transformation of open space in conservation area. The selected cases will be in Kotalama Semarang and Kotagede Yogyakarta. The study perform site observation and study cases to investigate and literature review to analyze the datas. The results were openspace transformations are unavoidable, the transformation are related to function and size, openspace can strengthen the conservation images.
\end{abstract}

Keywords: openspace; transformation; conservation; old and new; revitalization

\section{Introduction}

Urban environments have many kind of places such as squares, green spaces, or parks which able to provide socio-economic, environmental, and ecological benefits to the city and are indispensable for healthy urban living $[1,2,3]$. To develop the quality of the open outdoor environment and encourage more people to use the space is the ultimate purpose of urban space design $[4,5]$.

Semarang old city is a conservation area in Semarang city. This area is famous by nickname as little Netherland, because of Europe style in urban design which still properly preserved and conservated. Furthermore, this area is avital part of the urban environment,hosting functions and activities that are essential to the Semarang city character. The Semarang old city has Taman Srigunting that designed as public open spaces can be identified as communal spaces that attracted many people to come.

Kotagede is one of the many conservation area in Yogyakarta which part of Mataram Islam kingdom's capitol city (1588-1613). Furthermore, this area is a vital part of the Yogyakarta urban fringe environment, historical morphology and activities that are represent Yogyakarta past urban character. Kotagede has openspace called Lapangan Karang which support urban activities in the district.

In summary, Kotagede has Java traditional settlement character and Kotalama Semarang has Europe style urban design. However people activities and demands over open space changed through time. Human as social being has the demand of social interaction with a wide range from domestic to neighborhood scale. Children demand interaction with their parents and so does wife with her spouse husband and their relatives as well. In wider means of interaction, a person also needs to interact with his/her friends and makes a social group [6] .These example of interactions demand spaces to bring them occurred with more private for domestic interactions and public space for community interactions. In other hand, conservation shall be protected as part of historical site. Both area have requirements to be followed. The intersection between open space transformation and protected conservation area become this study object.

The purpose of this study is to investigate and analyze the transformation of open space in conservation area. The study perform site observation and study cases to investigate and literature review to analyze the datas.

\section{Methodology}

Open space is a place with specific area boundaries which being use together as community member. Open space also has meaning as place for communal activities or communal space. The Openspace can be determined as park, streetscape, atrium, plazza, waiting room, and indoor or outdoor public space which managed by government, private or communities[7]. Carr,et all[ 8] (1995) described open space transformation factors into five fundamental point [4], such as : origins, functions, activities, setbacks, surrounding buildings.

Literatures study and cases study were used as research methods. This study performs several literatures

* Corresponding author: bangunirh@ arsitektur.undip.ac.id 
of openspace design guidelines which already referenced by many cities, literature of universal design based studies which being adopted in many built environment facilities and some of related papers to construct the transformation item. The constructed item will be assessed to the selected open space at case studies in Kotagede Yogyakarta and Kotalama Semarang. Furthermore, the assesment results of two openspace explained and compared on data analysist.

\section{Result and Discussion}

\subsection{Brief Origin and Condition}

\section{Srigunting}

This center of Kotalama Semarang district was named Parade Plein. The name itself represent the function in the colonial era ( $17^{\text {th }}$ century) as military parade space. The location of military barack near parade plein emphasized the origin of the openspace. In the next period the parade plain was surrounded by many colonial buildings as the VOC area and government walled city. The parade plein turned into more diverse community oriented space with the installment of Blenduk church, enterteinment building Oudetrap, Marba warehouse, Justice court, etc. The activities and function become more vary with many type of people and the openspace shape-area automaticly changed to respon it. The location of Srigunting park is in the middle of the kota lama area as a red dot which can be seen in the figure 1 . In addition, the location of Srigunting in the past was not in the side of main road compared to present condition. The Jl.Letjend Suprapto street was being main road in early $19^{\text {th }}$ century as result of reduplication jembatan Berok which become the Kotalama Semarang entrance gate.

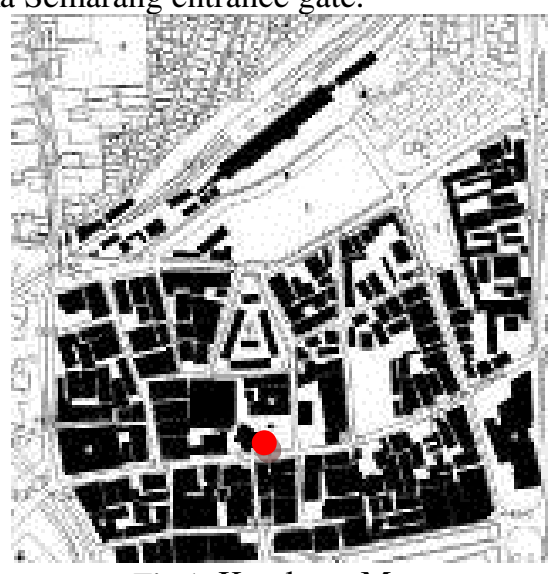

Fig 1. Kotalama Map

\section{Taman Karang}

This Kotagede biggest openspace is located next to the Kitren urban cemetery. Taman Karang have similarities with Mataram royal cemetery complex in the same region, such : least in front of cemetary (seperated by gate) and surrounded by housing of person in charge of the cemetery. The activities in Taman Karang were supporting the nyadran tradition and meeting place. In further development, the sport facilities such : soccer goal and lines, tribune and circular pavements. The location of Taman Karang is not in the middle of the area like Taman Srigunting to the Kotalama but in the far side of Kotagede center as red dot in figure 2. The location of taman Karang was highly related to it original function as transition space to urban cemetery Kitren. Refer to the term of open public space can be determined as park, streetscape, atrium, plazza, waiting room, and indoor or outdoor public space. The origin functions of Taman Karang are compilation of park, streetscape, atrium/plaza for waiting in outdoor area to enclosed cemetery.

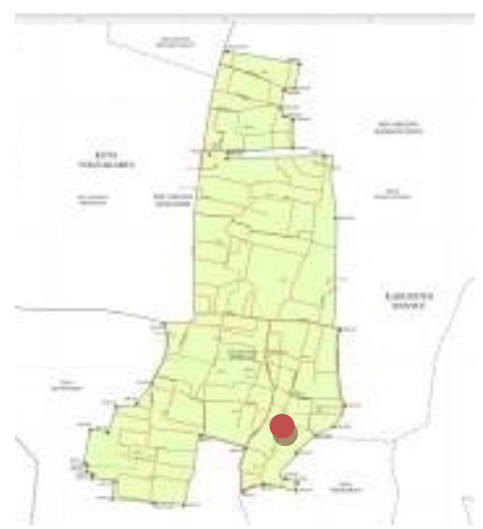

Fig 2. Kotagede Map

\subsection{Open space transformation factor}

Openspace is never been alone and surrounded by block of building or other spaces. The factors such origins, functions, activities, setbacks and surrounding buildings made the open space existence. In early 19th century the Srigunting was transformed from military parade landscape into other stages as been seen in figure 1. The setback of Gereja Blenduk and Jiwa Sraya Building enclosed the Taman as their communal yard after the end militery parade era (see figure 3 ). At that era the Srigunting was a plain area with low architectural detail. That condition brought the Srigunting unknown and meaning less sunk by the surrounding buildings value.

Later periods, the surrounding buildings will be the conservation objects in Kotalama Semarang with the local government regulation and still being processed into world tangible heritage under UNESCO flagship. However the Srigunting Park was not included in the list and proven by total renovation at 2010 with no origin pattern in the design process. 


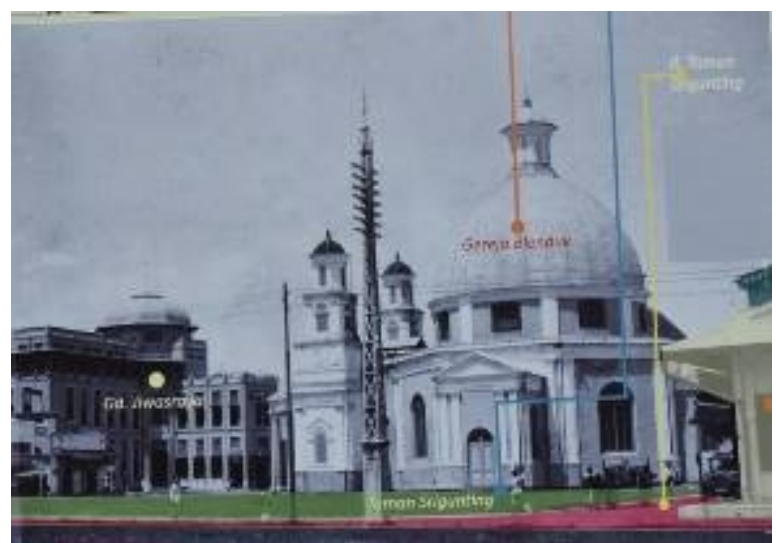

Fig 3. Srigunting in early 19th century

The condition of Kotagede openspace in Taman Karang in early 19th century showed another transformation story from place for nyadran supports into sport facilites (see figure 4). The dwellers made a circular street between cemetary to the taman and house. The street brought park isolation from the surrounding buildings. That condition made Taman Karang as single area with new function. During that period, sport facilities were highly demanded by Kotagede citizen. The size of Taman Karang able to provide soccer facilitation with spectator area around it.

Refer to the two openspaces case, the internal factor of openspace vacant condition meet the present demand of the citizen near the space brought a new activities and function to the openspace [11]. The citizens might not consider the status of conservation area to define the functions. However the alteration of function gradualy transform the openspace amenities.

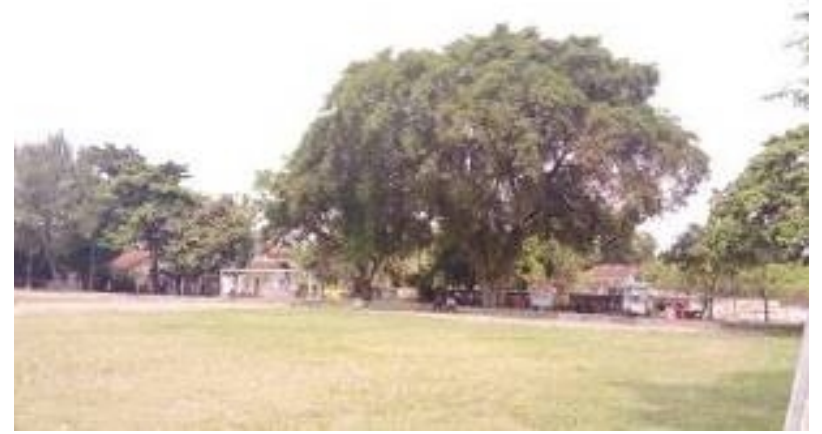

Fig 4. Taman Karang in early 20th century

\subsection{Openspace transformation items}

The transformation factors change the openspace shape, function, features detail and circulation [9]. Girouard [9] detailed that the transformation of open space :

[a] landscape shape,

[b] waterscape,

[c] stage form

[d] relaxation zone,

[e] restaurant

[f] architecture detail

[7] inner circulation.

However the aspects might not all fulfilled in openspace transformation. The transformations may mixed several mentioned items into one item due to complicated conditions on the site.

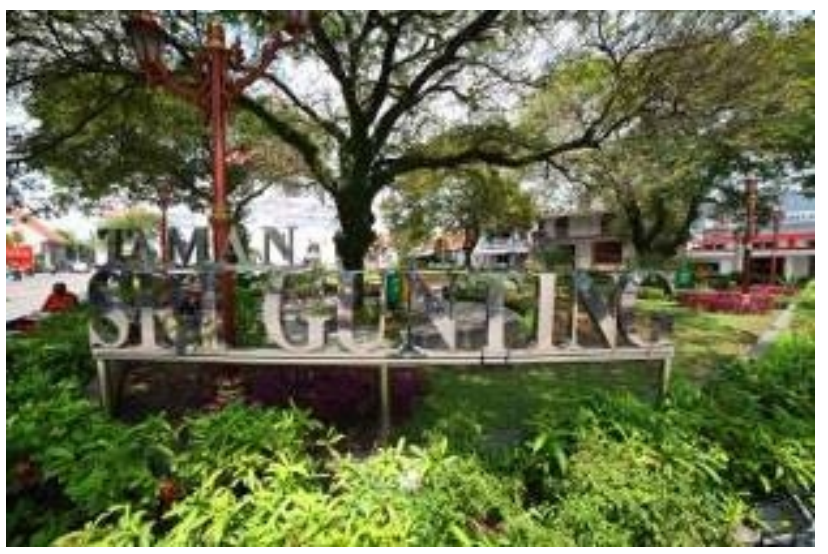

Fig 5. Present Srigunting

The Srigunting case showed that the function changes in the area provides new landscape shape, stage form, relaxation zone, architecture detail with inner circulation on it. The Srigunting didnt have any waterscape and restaurant. This conditions formed by location of nearest restaurants were at least a block away and by the kotalama situation at flood risk area. The citizen only do relaxation by sitting under the trees, taking pictures, and gathering with friends which stated by Tester [12] and Banarjee [11] as flaneurs and hanging out activities (see figure 5).

The Taman Karang case slightly different from the Srigunting. The Lansdcape re-shaped, stage formed, architecture detail installment, relaxation zone provided, and surprisely partial restaurant or food stall were established in Taman Karang [13]. The shape of park, soccer field stage rounded by pedestrian way and tribune made the Taman Karang become ideal place to relax and do culinary tourisme. The restaurant/food stalls only provide their food stall or gerobak and klasa or traditional carpets on the relaxation area to set their activities under the trees or food stall roofs and they generate others supports such : transportation and garbage disposal service .

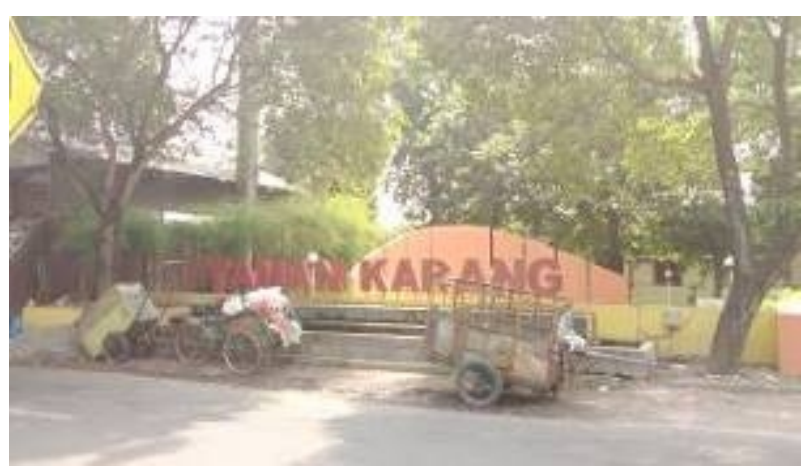

Fig 6 Present Taman Karang

Both openspace werent provided any waterscape since the conservation area might be have risk of flooding and the shaded trees condition with humid micro climate condition. The habit of strolling, looking 
and gathering of citizen attracts the local authority to provide facilities in openspace.

\subsection{Comparison study of Taman Srigunting and Taman Karang}

The transforming factors resulted public openspace transformation in many elements as described in previous chapters. The resumed result presented in table 1 showed the direct comparison between Taman Srigunting and Karang in origin and present state. The transformations were function, form, circulation, activities and identity. Transformations of each element were resulted the changes on others. Furthermore the citizen demand of openspace factors brought significant transformation.However the status of conservation seemed not affected

Table 1. Comparison of Srigunting and Karang

\begin{tabular}{|c|c|c|c|c|}
\hline \multicolumn{5}{|c|}{ Transformation } \\
\hline $\begin{array}{c}\text { Transformati } \\
\text { on } \\
\text { element }\end{array}$ & $\begin{array}{c}\text { Taman } \\
\text { Srigunting } \\
\text { (origin) }\end{array}$ & $\begin{array}{c}\text { Taman } \\
\text { Srigunting } \\
\text { (present) }\end{array}$ & $\begin{array}{l}\text { Taman } \\
\text { Karang } \\
\text { (origin) }\end{array}$ & $\begin{array}{c}\text { Taman } \\
\text { Karang } \\
\text { (present) }\end{array}$ \\
\hline Function & $\begin{array}{l}\text { Military } \\
\text { stage }\end{array}$ & $\begin{array}{l}\text { Thematic } \\
\text { urban park }\end{array}$ & $\begin{array}{c}\text { Nyadran } \\
\text { preparation }\end{array}$ & $\begin{array}{c}\text { Sport, } \\
\text { culinary } \\
\text { and } \\
\text { playground }\end{array}$ \\
\hline Form & $\begin{array}{l}\text { Lanscape, } \\
\text { stage, } \\
\text { architecture } \\
\text { detail, }\end{array}$ & $\begin{array}{c}\text { Lanscape, } \\
\text { stage, } \\
\text { architecture } \\
\text { detail, relaxation } \\
\text { zone, } \\
\text { innercirculation } \\
\text { Angling, } \\
\text { substraction, } \\
\text { open }\end{array}$ & Lanscape & $\begin{array}{c}\text { Landscape, } \\
\text { stage, } \\
\text { architecture } \\
\text { detail, } \\
\text { relaxation } \\
\text { zone, } \\
\text { restaurant } \\
\text { Addition, } \\
\text { regular, } \\
\text { closed }\end{array}$ \\
\hline circulation & $\begin{array}{l}\text { No inner } \\
\text { circulation }\end{array}$ & $\begin{array}{c}\text { Inner } \\
\text { circulation } \\
\text { with clustering }\end{array}$ & $\begin{array}{l}\text { No inner } \\
\text { circulation }\end{array}$ & $\begin{array}{l}\text { No inner } \\
\text { circulation }\end{array}$ \\
\hline activities & parade & $\begin{array}{l}\text { Thematic } \\
\text { urban space }\end{array}$ & $\begin{array}{l}\text { Family } \\
\text { gathering }\end{array}$ & $\begin{array}{c}\text { Sport, } \\
\text { culinary } \\
\text { and } \\
\text { playground }\end{array}$ \\
\hline identity & Military & $\begin{array}{c}\text { Kotalama } \\
\text { Urban park }\end{array}$ & cemetary & $\begin{array}{l}\text { Community } \\
\text { space }\end{array}$ \\
\hline
\end{tabular}

The inner circulation only appear on present Srigunting park as result of relaxation zone clustering (see figure 7). The previous srigunting and taman karang were having circulation on the outer park area. The inner park of previous Srigunting and Karang were functioned as main event of parade or other activities which need big stage.

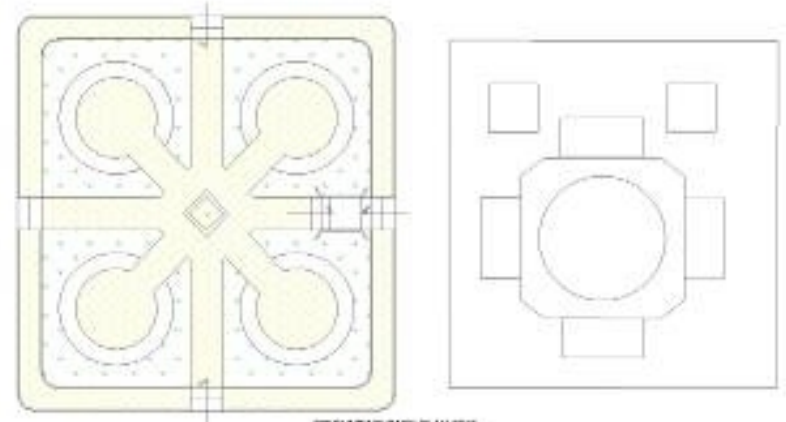

Figure 7 Srigunting park plan 2011

The transformation in open space identity also conducted at the study cases. The transformation of
Srigunting park as military identity slowly turned into Urban park, since the military stopped the parade routinity. At other side, Taman Karang transformed their identity from cemetary area into community space as nowadays the citizen highly demanded for open communal space rather than transition to the cemetary. However the identity is a new principle of universal design which role a fundamental base on design [14]. Those place identities have not represent the heritage conservation area itself. That conditions may brought problems in developing this open space at next stage, since the fundamental base is community rather than heritage issues. Unless, the communities become parts of heritage itself.

The transformation factors of openspace werent included the conservation regulation.. In aims to preserve the heritage further, local regulations need to be updated with more sustainable aspect and applied strictly in projects[15].

\section{Conclussion}

The Taman Srigunting in Kotalama Semarang and Taman Karang in Kotagede Yogyakarta were openspace in conservation area which being transformed by citizen demands, activities, functions, surrounding building form through several periods. The transformation factors of openspace werent included the conservation regulation. However the surrounding building and environment must follow the conservation regulations. In addition, the significant impact of surrounding community in openspace shall be seriously included in the next development of herigae area. This study suggest further study of conservation area impact in public open space and the importance of conserving openspace for heritage.

\section{References}

1. J. Gehl, Life between buildings : Using Public Space, sixth ed., (The Danish Architectural Press. Copenhagen. Denmark, 2006).

2. W.H. Whyte, City: rediscovering the center. (Doubleday. New York, 1988).

3. J. Jacobs. The death and life of great american cities. (Penguin, Harmondsworth, 1972).

4. J. Zacharias, T. Stathopoulos, H. Wu, Environ. Behav. 36 p638-658 (2004).

5. J. Zacharias, T. Stathopoulos, H. Wu. Environ. Behav. 33, p296-315 (2001).

6. Stangor C, Social groups in action and interaction, (Psychology Press, New York, 2004)

7 A. Madanipour, Design of Urban Space- An Inquiry Into a Socio- Spatial Process (England: John Willey \& Sons, 1996)

8 S. Carr, F. Mark, L. Rivlin, A. Stone. Public Space. (Cambridge University Press, Australia, 1995)

9 M. Girouard, Cities \& People : A Social and Architecture History (Yale University Press, USA, 1995) 
10 M. Carmona, T. Heath, T. Oc, Public Plaes Urban Spaces : The Dimension of Urban Design, (Architectural Press, London, 2003)

11 T. Banarjee, Journal of American Planning Association, 67-1, p 9-24 (2001)

12 Tester, K, (Ed.). The flâneur (New York: Routledge, 1994).
13 M. Pusporetno, JDP , 1-1 (2014)

14 Bangun IR Harsritanto, E3S Web of Conferences, 31, 09010 (2018)

15 Indrakusumo, Bangun, Design Characteristics of Specialized Streets for Indonesia through Cases of South Korea, (Doctoral's thesis, Pukyong National University, South Korea, 2016) 